Jerzy Sawicki

Zachodniopomorski Uniwersytet Technologiczny w Szczecinie

ORCID 0000-0002-1134-4437

Andrzej Kajetan Wróblewski

Uniwersytet Warszawski

\title{
Jak Józef Herman Osiński został obdarzony obliczem lorda Kelvina. Proces poszlakowy
}

\section{How Józef Herman Osiński Was Given the Face of Lord Kelvin. A Circumstantial Trial}

Fifty years ago, a portrait of Józef Herman Osiński, an eminent Polish physicist and electrician of the $18^{\text {th }}$ century, was suddenly 'discovered' and published in a book on famous electricians. We present solid evidence that the purported portrait was in fact that of Lord Kelvin, which by an editorial mistake was labeled with the name of Osiński.

Keywords: Józef Herman Osiński, history of physics and science of electricity in Poland Słowa kluczowe: Józef Herman Osiński, historia fizyki i nauki o elektryczności w Polsce

Wstęp

Sto kilkadziesiąt lat po śmierci Józefa Hermana Osińskiego pojawiła się w polskich publikacjach naukowych jego rzekoma podobizna. Zaczęło się od książki popularnonaukowej, ale z czasem coraz większa liczba autorów piszących o Osińskim bezkrytycznie przyjęła nowy portret za prawdziwy - nie interesując się jego pochodzeniem i autorstwem - powielając fałszywą podobiznę w swoich publikacjach. Mija właśnie pół wieku funkcjonowania fałszywego portretu Osińskiego w naszym obiegu naukowym i popularnonaukowym. Czas najwyższy wyjaśnić przyczyny tego fatalnego błędu i kolejność zdarzeń oraz wskazać osoby, które się do tego przyczyniły i najważniejsze fakty. Potraktujmy to jako proces poszlakowy, w którym jednakże przytoczymy twarde dowody, wskażemy podejrzanych oraz wymienimy szkody, jakie wyrządziła ta sprawa naukowej rzetelności i wiarygodności.

Udowodnimy, że rzekomy portret Osińskiego przedstawia bez cienia wątpliwości Williama Thomsona vel lorda Kelvina. Józef Osiński pozostanie odtąd bez podobizny, ale i bez zarzutu, że jako osiemnastowieczny członek zakonu pijarów nosił długą i gęstą brodę. 
Ta charakterystyczna broda była przyczyną pewnych wątpliwości wśród niektórych badaczy historii nauki, gdyż na twarzach znanych postaci polskich pijarów z XVIII w. zarost był niewidoczny. Jednak ostateczne rozprawienie się z fałszywym portretem Osińskiego wymaga wskazania innej osoby, która do portretu pozowała. Przedstawimy pod osąd Czytelnika niezbite dowody, że inkryminowany portret przedstawia Brytyjczyka, a nie Polaka.

\section{Przedmiot procesu}

Nasze śledztwo i proces dotyczą bezprawnego wykorzystania wizerunku lorda Kelvina do przedstawienia osoby Józefa Hermana Osińskiego bez wiedzy i zgody obydwu poszkodowanych osób. Główne dowody w sprawie to autentyczne obrazy portretowe lorda Kelvina i fałszywa kopia podpisana nazwiskiem Osińskiego.

\section{Dramatis personae}

Przedstawmy pokrótce najważniejszych uczestników naszego procesu. Na początek poszkodowani. Zacznijmy od najważniejszego poszkodowanego, czyli Osińskiego, któremu odebrano należne mu wizerunkowe incognito - człowiek tej miary, gdyby zechciał, z pewnością postarałby się za życia o swój portret - przypisując mu obcą twarz, czego z pewnością, jak każdy uczciwy człowiek, by sobie nie życzył. Kazimierz Osiński urodził się w 1738 r. w Dobrzykowie, niedaleko Płocka. W wieku 17 lat wstąpił do zakonu pijarów i od tego czasu używał zakonnych imion Józef Herman. W latach 1768-1772 przebywał w Wiedniu i Paryżu jako opiekun młodocianego arystokraty Stanisława Sołtyka. Osińskiego pasjonowała fizyka i podczas wyjazdu chłonął najnowszą wiedzę z książek i bezpośrednich kontaktów z uczonymi. Po powrocie do Warszawy rozpoczął wykłady w Collegium Nobilium. Pierwszym ważnym dziełem Osińskiego jest wydany w 1777 r. podręcznik Fizyka doświadczeniami potwierdzona. Osiński miał wszechstronne zainteresowania i napisał jeszcze kilka innych wartościowych książek, między innymi: Nauka o gatunkach i szukaniu rudy żelazney (1782), Gatunki powietrza odmiennego od tego, w ktorem żyjemy, krodko zebrane, sposoby nabywania ich opisane, własności doswiadczeniami potwierdzone, zażycie iednych do robienia wod leczących, lub strzelania, innych na dochodzenie, ktore powietrze zdrowe etc. (1783), Robota machiny powietrznej pana Mongolfier (1784) oraz Sposob ubespieczający życie y maiątek od piorunów (1784). Za tę ostatnią pracę Józef Osiński jest szczególnie honorowany w środowisku polskich elektrotechników, uznających uczonego za pierwszego polskiego elektryka. Jako jeden z nielicznych polskich uczonych epoki stanisławowskiej korespondował w sprawach naukowych z wybitnymi uczonymi z zagranicy, m.in. z Williamem Herschelem. Osiński zmarł w Warszawie w 1802 roku w wieku 64 lat.

Drugim poszkodowanym w naszym procesie jest niewątpliwie lord Kelvin, którego wizerunkiem bezprawnie posługiwali się polscy autorzy i wydawcy, w zastępstwie nieistniejącego portretu Osińskiego. Kelvin nie ma już możliwości obrony własnego wizerunku, wystąpimy zatem w jego imieniu. William Thomson, gdyż takie było jego właściwe imię i nazwisko, urodził się w 1824 r. w Belfaście. Studiował fizykę i matematykę na uniwer- 


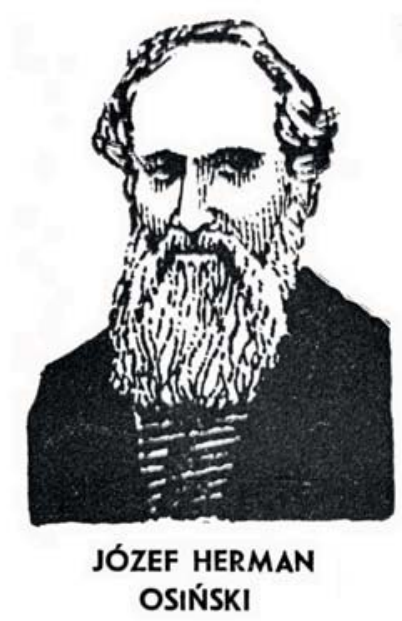

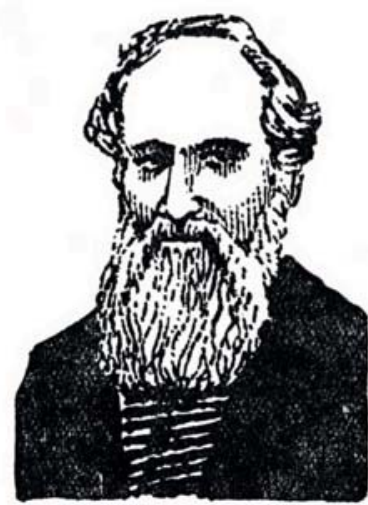

WILLIAM THOMSON (LORD KELVIN)

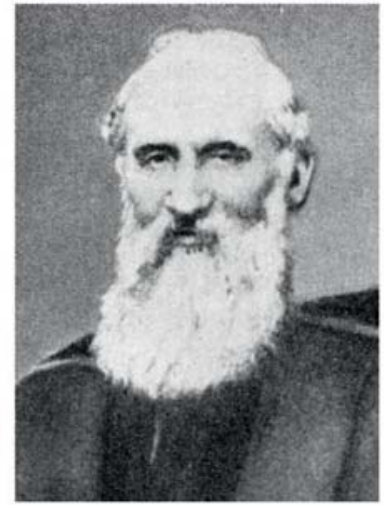

Wycinek portretu Williama Thomsona

Ryc.1. Od lewej: grafika z podpisem ilustrująca biogram Osińskiego w książce S. Weinfelda Poczet wielkich elektryków (1968), grafika z podpisem ilustrująca biogram lorda Kelvina w książce R. Sobiesiaka Poczet wielkich fizyków (1969), wycinek portretu lorda Kelvina zamieszczony w książce E. Porębskiego Wielcy twórcy nauki (1939).

sytetach w Glasgow, Cambridge i paryskiej Sorbonie. W wieku 22 lat został profesorem filozofii naturalnej na uniwersytecie w Glasgow. Najważniejsze prace Thomsona dotyczą nauki o cieple, w której m.in. podał jedno ze sformułowań drugiej zasady termodynamiki oraz wprowadził nową bezwzględną skalę termometryczną, w której stopnie (obecnie nazywane na jego cześć kelwinami) liczymy od zera bezwzględnego. Zajmował się również elektrycznością (a zatem nie tylko wspólny wizerunek, ale i jedna z uprawianych dyscyplin łączy obie poszkodowane postacie).

W tej ostatniej dziedzinie miał znaczące osiągnięcia inżynierskie. Za swoje dokonania, zwłaszcza za kierowniczą rolę w ułożeniu podmorskiego kabla telegraficznego między Europą i Ameryką, otrzymał tytuł lorda Kelvina. Zmarł w 1907 r. w wieku 83 lat. Pochowany został w opactwie westminsterskim obok Isaaca Newtona.

Trzecim poszkodowanym jest zbiorowość P.T. Czytelników, wprowadzonych w błąd fałszywym portretem Józefa Osińskiego. To najważniejsi poszkodowani, ufni w prawdziwość informacji podawanych w publikacjach naukowych, srogo się w tym przypadku zawiedli.

Oskarżeni. Redakcja Instytutu Wydawniczego „Nasza Księgarnia” z lat sześćdziesiątych XX w., Stefan Weinfeld (1920-1990) - pisarz, publicysta i popularyzator nauki - a ponadto późniejsi autorzy publikacji naukowych, którzy zamieszczając rzekomy portret Osińskiego, nie zadali sobie trudu zweryfikowania jego pochodzenia i autentyczności. Zarzutów nie stawiamy samemu autorowi ilustracji, Mateuszowi Gawrysiowi (1926-2003), redaktorowi artystycznemu wydawnictwa „Nasza Księgarnia”. Był on znanym malarzem, grafikiem i ilustratorem książek, przeznaczonych dla dzieci i młodzieży. Naszym zdaniem nie ponosi odpowiedzialności za sposób wykorzystania jego prac. 
Świadek. Istotnym uczestnikiem naszego dochodzenia może okazać się Eugeniusz Jan Porębski (1889-1960)' ${ }^{1}$, inżynier mechanik, absolwent Politechniki Lwowskiej, popularyzator nauki i techniki, autor książki Wielcy twórcy nauki², która dzięki licznym wydaniom spopularyzowała w Polsce sylwetkę i portret lorda Kelvina, a także wielu innych wybitnych postaci świata nauki i techniki.

\section{Osiński bez portretu}

Wkład Józefa Hermana Osińskiego w rozwój polskiej nauki i szkolnictwa został zauważony i doceniony już w XIX wieku. Należał on do członków założycieli Towarzystwa Warszawskiego Przyjaciół Nauk w 1800 r. Po przedwczesnej śmierci uczczono jego pamięć na specjalnej sesji Towarzystwa. ${ }^{3}$ Kiedy nasz wybitny historyk Aleksander Kraushar (1843-1931) zbierał materiały do swej monumentalnej dziewięcioczęściowej monografii Towarzystwa ${ }^{4}$, przeszukał wszystkie dostępne wówczas archiwa, ale nie znalazł podobizn niektórych członków, m.in. właśnie Osińskiego. Podobizna Osińskiego nie pojawiła się również w bogato ilustrowanych polskich encyklopediach. ${ }^{5}$

W 1934 r., w 150 rocznicę wydania książki Osińskiego Sposob ubespieczający życie y maiątek od piorunów, ukazał się okolicznościowy artykuł Tadeusza Żerańskiego Ks. Józef Herman Osiński, pierwszy elektryk polski ${ }^{6}$. W publikacji tej zebrano wiele wartościowych wiadomości o życiu i dziele Osińskiego, niestety nie uniknięto też błędów. Fałszywe jest twierdzenie Żerańskiego, że Osiński prowadził swoje wykłady wyłącznie po francuskư ${ }^{7}$, a także wymienienie trzeciego (1806) i czwartego (1810) wydania jego podręcznika fizyki ${ }^{8}$. W artykule zamieszczono widok karty tytułowej książki Osińskiego o ochronie przed piorunami. Gdyby dostępny był portret uczonego, z pewnością również znalazł by się w tej publikacji.

Prawdopodobnie zatem nigdy nie było żadnego portretu Osińskiego i trzeba pogodzić się z faktem, że znać go będziemy tylko przez jego dzieła i relacje mu współczesnych.

1 J. Kubiatowski, Biogram Eugeniusza Jana Porębskiego, [w:] Internetowy Polski Słownik Biograficzny, ipsb.nina. gov.pl/a/biografia/eugeniusz-jan-porebski [dostęp 6.12.2018].

2 E. Porębski, Wielcy twórcy nauki, wyd. 1, Warszawa 1934, wyd. 2, Warszawa 1939.

3 Mowa miana przez Stanisława Sołtyka na pamiątkę X. Osińskiego Piiara, dnia 24 Maia 1804 roku, „Roczniki Towarzystwa Warszawskiego Przyjaciół Nauk" t. 4, 1807, s. 12-30; to samo w: „Nowy Pamiętnik Warszawski” t. 15, lipiec 1804, s. 109-126. Stanisław Sołtyk (1752-1833) był wybitnym działaczem polityczno-społecznym, posłem na Sejm Czteroletni, inicjatorem Towarzystwa Warszawskiego Przyjaciół Nauk w 1800 r.

4 A. Kraushar, Towarzystwo Warszawskie Przyjaciół Nauk 1800-1832, t. 1-9, Kraków-Warszawa 1900-1911.

5 S. Orgelbranda Encyklopedja powszechna z ilustracjami i mapami, t. 1-18, Warszawa 1898-1912; Wielka Encyklopedja Powszechna Ilustrowana, t. 1-55, Warszawa 1892-1914.

6 T. Żerański, Ks. Józef Herman Osiński, pierwszy elektryk polski (W 150-tą rocznicę ogłoszenia drukiem pierwszej polskiej książki elektrotechnicznej), „Przegląd Elektrotechniczny” t. 16, 1934, nr 14, s. 449-452.

7 Autor artykułu nie sięgnął do źródeł, lecz uwierzył anonimowej notatce w „Tygodniku llustrowanym” z 1868 r. Tymczasem w oryginalnym doniesieniu w „Gazecie Warszawskiej” (1.05.1779) czytamy: „Xiądz Osiński Scholarum Piarum Professor Fizyki Experymentalney in Collegio Nobilium, będzie miewał Lekcye publiczne po polsku z Fizyki Experymentalney, ze wszystkiemi doświadczeniami. Te Lekcye będzie miewał sposobem Cudzoziemskim w Sali Teatralney; Zacznie ie dnia 4 Maia, y oneż miewać będzie przez May, Czerwiec, y Lipiec na tydzień trzy razy; to iest; we Wtorki, Czwartki y Soboty, od godziny czwartey aż do piątey (Święta się excypuią) Na te Lekcye, w których cały Kurs skończyć spodziewa się, zaprasza. Materye fizyczne tym porządkiem wyłoży, który się znayduie w Fizyce przez niego wydaney".

8 Autor nie widział tego podręcznika, więc uwierzył datom. Tymczasem w rzeczywistości było tylko wydanie trzecie, w dwóch tomach, wydanych w odwrotnej kolejności: tom 2 w 1806 r., a tom 1 w 1810 r. 
Wszystkie ślady i wyniki poszukiwań prowadzą do wniosku, że życie fałszywego portretu Józefa Hermana Osińskiego zaczęło się w 1968 r. w książce Stefana Weinfelda Poczet wielkich elektryków ${ }^{9}$. Niewielkich rozmiarów grafika autorstwa Mateusza Gawrysia pojawiła się przy biogramie Józefa Hermana Osińskiego nie zwracając większej uwagi. Można by sądzić, że fakt pojawienia się poszukiwanego wizerunku Osińskiego rozbłyśnie jak kometa na niebie w gronie historyków nauki. Recenzja książki Weinfelda pióra Jerzego Kubiatowskiego ${ }^{10}$ ukazała się w poważnym czasopiśmie wydawanym przez PAN i była to opinia bardzo pozytywna. Kubiatowski był z wykształcenia inżynierem elektrykiem, a z zawodu dziennikarzem, pasjonatem historii nauki i techniki, biografistą; w sumie ogłosił około 800 artykułów ${ }^{11}$. W uwagach krytycznych swojej recenzji odnotował brak podobizn rysunkowych niektórych osób i upomniał się o nie, wymieniając nazwiska Bairda, Biernackiego i Podoskiego. Błędu w wizerunku Osińskiego jednak nie dostrzegł.

Rzeczywiście w książce Weinfelda brakuje kilku portretów i to doskonale znanych osób, np. Musschenbroeka, jednak najważniejsze dla nas znaczenie ma fakt, że portretu brak przy biogramie Williama Thomsona! Ten portret w książce jednak jest, ale przez pomyłkę redakcji trafił na stronę z biogramem Osińskiego. Należy też wspomnieć, że w wydanej przez „Naszą Księgarnię” rok później książce Ryszarda Sobiesiaka Poczet wielkich fizyków znalazł się również biogram Williama Thomsona opatrzony znaną nam już grafiką, tym razem prawidłowo powiązaną z tekstem.

Pojawia się naturalnie pytanie, dlaczego błąd autora książki i wydawnictwa nie został od razu dostrzeżony i wyjaśniony. Dlaczego powielany był przez okrągłe pół wieku w polskim piśmiennictwie? Błędy i pomyłki zdarzają się wszak wszystkim, a wedle znanego powiedzenia przypisywanego Konfucjuszowi „Kto wie, że popełnił błąd i nie próbuje go naprawić, popełnia drugi błąd. Prawdziwym błędem jest błąd popełnić i nie naprawić go". Szukając okoliczności łagodzących, należy przyznać, że książka Weinfelda była przeznaczona dla młodzieży, ze względu na tematykę - wielcy elektrycy - miała stosunkowo mały krąg odbiorców, a jej popularny charakter sprawił, że nie docierała do profesjonalnych historyków nauki. Tych ostatnich było zapewne w tamtym czasie niewielu. Książka Weinfelda nie zawierała nazwisk recenzentów, ani redaktora prowadzącego serię biografii uczonych z różnych dziedzin. Ukazały się bowiem w podobnej szacie graficznej inne pozycje książkowe z tej serii, omawiające wielkich fizyków, matematyków, chemików, biologów, astronomów, itd. Obie książki, o wielkich elektrykach i fizykach, były redagowane w wydawnictwie "Nasza Księgarnia” w niedługim odstępie czasu, a ukazały się odpowiednio w 1968 i 1969 r. Nie ulega wątpliwości, że ta sama grafika Mateusza Gawrysia została użyta dwa razy, przy biogramach różnych osób: Osińskiego i Thomsona.

Domniemanie niewinności nakazuje dopuszczenie myśli, że może Mateusz Gawryś lub redakcja dysponowali jakimś nieznanym dotąd portretem Osińskiego, który odegrał rolę

9 S. Weinfeld, Poczet wielkich elektryków, Warszawa 1968, s. 30.

10 S. Weinfeld, Poczet wielkich elektryków, Warszawa 1968, rec. J. Kubiatowski, „Kwartalnik Historii Nauki i Techniki" t. 15, 1970, nr 2, s. 367-368.

11 B. Orłowski, Z. Wójcik, Jerzy Kubiatowski (1922-1995), „Kwartalnik Historii Nauki i Techniki” t. 41, 1996, nr 2, s. $145-152$. 


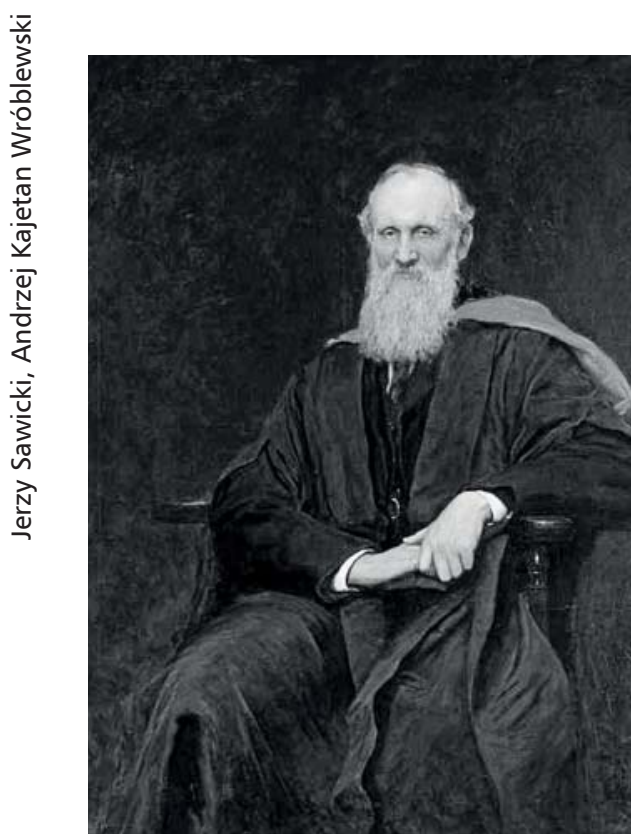

Ryc. 2. Lord Kelvin (1824-1907), obraz Huberta von Herkomera z 1896 r. ze zbiorów Glasgow Museum.

pierwowzoru dla pracy grafika. Może to nie Osińskiemu, a Thomsonowi przyporządkowano błędny wizerunek? Udowodnimy, że tak nie było. Prostym sposobem rozstrzygnięcia wątpliwości jest porównanie autentycznych portretów Thomsona z grafiką opracowaną przez Gawrysia. Otóż nie ulega najmniejszej wątpliwości zgodność grafiki ilustracyjnej z portretem lorda Kelvina namalowanym przez Huberta von Herkomera. Oryginał portretu znajduje się w muzeum w Glasgow. Grafik „Naszej Księgarni" nie musiał jednak odbywać dalekiej podróży, aby na podstawie portretu wykonać swoją ilustrację.

Powołamy w tym miejscu na świadka dzieło Eugeniusza Jana Porębskiego zatytułowane Wielcy twórcy nauki, zawierające sylwetki wybitnych uczonych i ich portrety. Książka Porębskiego wydana po raz pierwszy w 1934 r., miała drugie, nieco zmienione, wydanie w 1939 r., a po II Wojnie Światowej ukazała się w 1960 r. pod nowym tytułem Ludzie którzy zmieniali świat i do dziś jest łatwo dostępna w bibliotekach i antykwariatach. Książka zawierała około 70 biogramów i 58 portretów uczonych, w tym Williama Thomsona.

Jest wysoce prawdopodobne, że to na podstawie portretu z książki Porębskiego wykonał swoją grafikę Mateusz Gabryś pod koniec lat sześćdziesiątych ubiegłego wieku. Poza narysowaniem kreskowej podobizny Thomsona, Gawryś sporządził także kilkanaście innych podobizn uczonych wykorzystanych w Poczcie Wielkich Fizyków, które są uderzająco podobne do rycin zamieszczonych przez Porębskiego (poza Thomsonem także np. Ampère'a, Archimedesa, Carnota, Galvaniego, Guerickego, Gaussa i innych).

Redakcja „Naszej Księgarni” nie usiłowała za wszelką cenę dopasowywać portretu do każdego biogramu, więc gdy pojawiał się problem, miejsce na wizerunek pozostawało puste. Kiedyś, przy ręcznym składaniu tekstów przeznaczonych do druku, chętnie zrzuca-
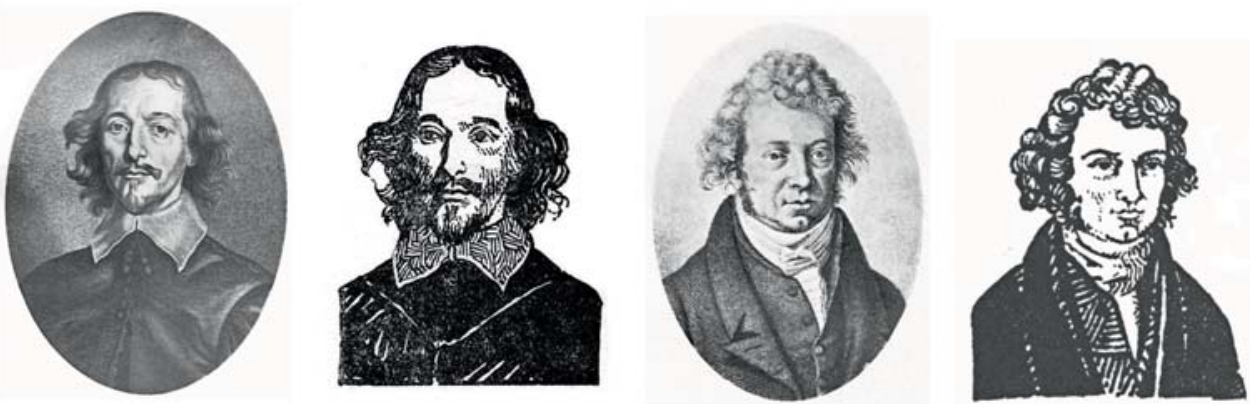

Ryc. 3. Przykładowe zestawienia portretów uczonych: Otto Guerickego oraz André Marie Ampère'a z książki Porębskiego z odpowiednimi grafikami Mateusza Gabrysia). 

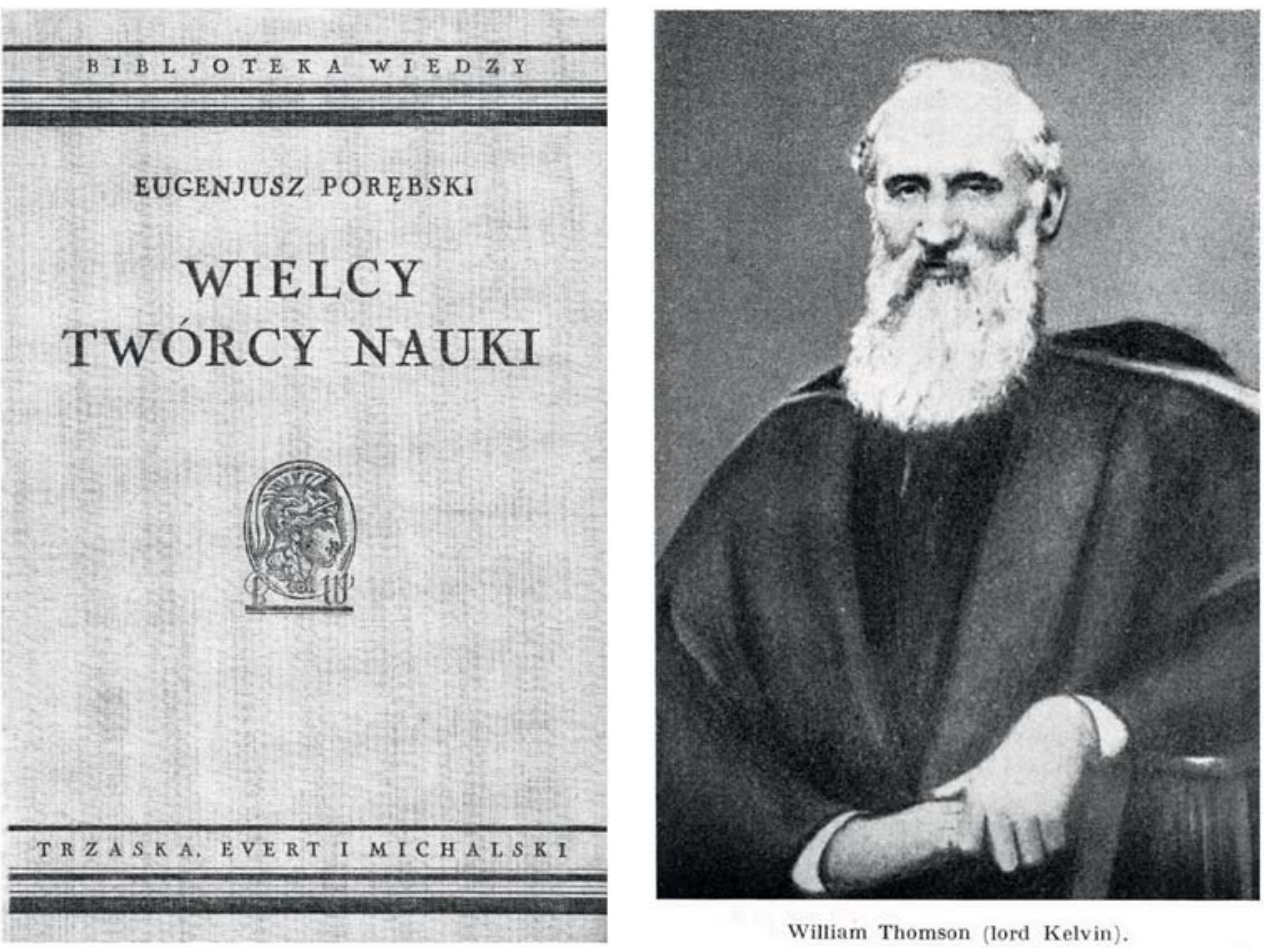

William Thomson (lord Kelvin).

Ryc. 4. Okładka książki Porębskiego i zamieszczony w niej portret Williama Thomsona.

no winę za mimowolne błędy i brak skutecznej korekty na chochlika drukarskiego. Zapewne coś podobnego zdarzyło się w redakcji z grafiką przedstawiającą lorda Kelvina.

Mogłoby się wydawać, że jednorazowa redakcyjna pomyłka, polegająca na nieprawidłowym umieszczeniu wizerunku Thomsona, nie będzie miała istotnych konsekwencji. Sprawy potoczyły się jednak inaczej. Środowisko polskich elektrotechników zaczęło w latach osiemdziesiątych XX w. interesować się swoją historią, szukać rodowodu tej dyscypliny, dokumentować wydarzenia historyczne i poszukiwać pierwszych polskich elektryków. Józef Herman Osiński doskonale nadawał się na pioniera polskiej elektrotechniki. Co prawda elektrotechnika wyodrębniła się z fizyki dopiero pod koniec XIX w., to jednak książka Osińskiego zatytułowana Sposób ubespieczaiący życie y majątek od piorunów wydana w 1784 r. w Warszawie dotyczyła zagadnień, którymi elektrotechnika zajmuje się również współcześnie, używając nowszego określenia: technika ochrony odgromowej.

Pewnie nie da się już ustalić osoby, która pierwsza „odkryła” portret Osińskiego w książce Weinfelda i zaczęła używać go jako prawdziwej podobizny naszego uczonego. Wiemy jednak, że już w latach osiemdziesiątych XX w. posługiwano się tym falsyfikatem bez zastrzeżeń. Z biegiem czasu liczba publikacji korzystających z tego obrazka wzrastała i niepozorny portret, jak śnieżna kula, obrastał kolejnymi kopiami, ulepszeniami, uznaniem i z czasem nawet specyficzną tradycją. Apogeum tego procesu przypadło na rok 2018, obchodzony przez Stowarzyszenie Elektryków Polskich jako Rok Józefa Hermana Osińskiego. Spektakularnym zakończeniem obchodów było uroczyste odsłonięcie pomnika Osińskiego w Rzeszowie. Pomnik, zbudowany z dwóch wielkich szklanych tablic 
ozdobiła naturalnie podobizna Osińskiego. Ale o tym i innych przypadkach wykorzystania fałszywego wizerunku będzie mowa w dalszej części.

\section{Pół wieku życia „portretu” Osińskiego}

Jak już wspomniano, rzekomy portret Osińskiego nie od razu zdobył sobie popularność. Milowy krok naprzód dokonał się za sprawą pomysłu Zarządu Głównego Polskiego Towarzystwa Elektrotechniki Teoretycznej i Stosowanej (PTETiS) z 1984 r., aby uhonorować ośmiu wybitnych polskich elektryków serią znaczków pocztowych z ich podobiznami ${ }^{12}$. Powołana komisja (Andrzej Marusak i Jacek Przygodzki) ustaliła, że na znaczkach powinni się znaleźć: Józef Herman Osiński, Julian Ochorowicz, Napoleon Nikodem Cybulski, Michał Doliwo-Dobrowolski, Ignacy Mościcki, Roman Podoski, Kazimierz Drewnowski i Janusz Groszkowski.

Do wydania serii znaczków jednak nie doszło. Prawie cała ósemka budziła w czasach PRL-u zastrzeżenia, zwykle natury politycznej. Przeciwko umieszczeniu wśród polskich elektryków Michała Doliwo-Dobrowolskiego zaprotestował Zarząd PTETiS; stwierdzono, że polskie pochodzenie Doliwo-Dobrowolskiego jest „problematyczne”, a poza tym w ZSRR ukazały się już dwa znaczki przedstawiające jego podobiznę jako wielkiego uczonego rosyjskiego. Również osoba Ignacego Mościckiego, prezydenta RP w latach 1926-1939 nie budziła entuzjazmu we władzach PRL. Osiński z kolei reprezentował kościół katolicki, a Groszkowskiemu pamiętano sprzeciw wobec konstytucji PRL z 1976 r. Nie wiemy, co ostatecznie wpłynęło na decyzję Ministerstwa Łączności nadzorującego emisję znaczków pocztowych, w każdym razie serii tej nie wydano.

Jednak pomysł upamiętnienia wybitnych polskich elektryków przez PTETiS nie tylko nie upadł, ale uległ rozszerzeniu. W następnych latach opracowano i wydano plakat zatytułowany Poczet pierwszych elektryków polskich urodzonych do końca XIX wieku.

Pieczęć Polskiego Towarzystwa Elektrotechniki Teoretycznej i Stosowanej, przyłożona do falsyfikatu portretu Józefa Osińskiego ośmieliła inne osoby i instytucje do posługiwania się tym samym „portretem” Osińskiego w swoich publikacjach, dokumentach, a w późniejszych czasach także na stronach internetowych.

Znaczną rolę w popularyzacji osoby i dokonań Józefa Osińskiego odegrało Stowarzyszenie Elektryków Polskich. Niestety i tu nie zastanawiano się wiele nad autentycznością wizerunku Osińskiego. W 2015 r. SEP zainaugurował coroczne Sympozja Historii Elektryki. W materiałach z pierwszej konferencji, która odbyła się w Gdańsku, znaleźć można publikację zatytułowaną tak samo jak wcześniejszy plakat PTETiS ${ }^{13}$. Przy okazji należy zauważyć, że w publikowanych zestawieniach pierwszych polskich elektryków brakuje Józefa Rogalińskiego (1728-1802), autora pierwszej publikacji w języku polskim poświęconej elektryczności ${ }^{14}$, ale przede wszystkim uderza pominięcie gdańszczanina Daniela Gralatha (1708-1767), którego osiągnięcia w dziedzinie elektryczności są znane na całym świecie.

12 Polskie Towarzystwo Elektrotechniki Teoretycznej i Stosowanej, Wielcy Elektrycy Polscy, marie-www.ee.pw.edu. $\mathrm{pl} / \mathrm{sep}-\mathrm{ow} / \mathrm{PLI} / \mathrm{wep} . \mathrm{htm}$ [dostęp 6.12.2018].

13 A. Demenko, J. Hickiewicz, Poczet pierwszych elektryków polskich urodzonych do końca XIX wieku, „Zeszyty Naukowe Wydziału Elektrotechniki i Automatyki Politechniki Gdańskiej" nr 44, 2015, s. 117-125.

14 J. Rogaliński, O Dziwnych Bursztynowania Skutkach Rozmowa y Popis Publiczny z Wytłumaczeniem Niektórych szczegulnieyszych Doswiadczen, Poznań 1766. 


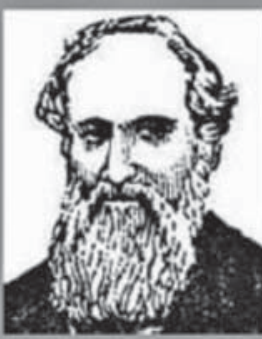

Józef Herman Osinski (1738-1802)

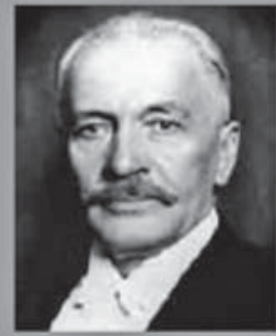

Ignacy Modcicki (1867-1946)

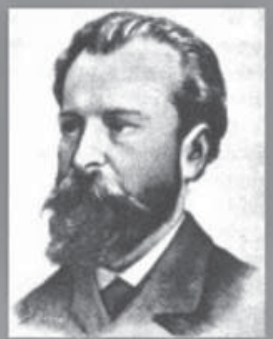

Julian Ochorowicz (1850-1917)

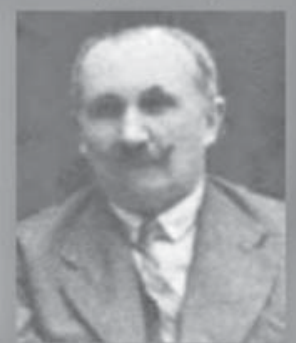

Roman Podoski (1873-1954)

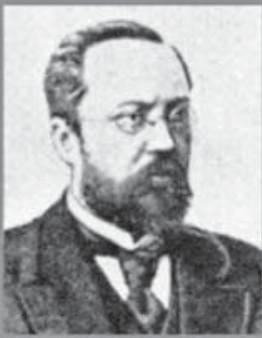

Napoleon Nikodem Cybulski (1856-1919)

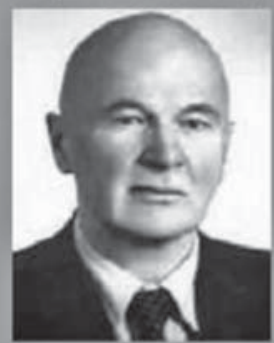

Kazimierz Drewnowski (1881-1952

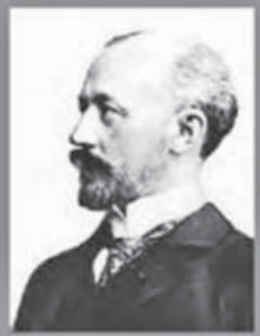

Michat Doliwo-Dobrowolski (1862-1919)

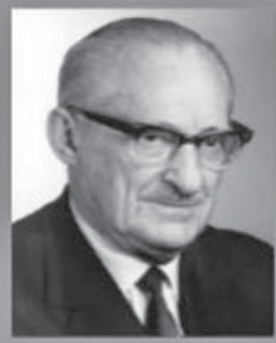

Janusz Groszkowski (1898-1984)

Ryc. 5. Sylwetki Wielkich Elektryków Polskich przygotowane przez PTETiS w 1984 r.

\title{
Elektrotechniki Teoretycznej i Stosowanej
}

\section{Polskie Towarzystwo}

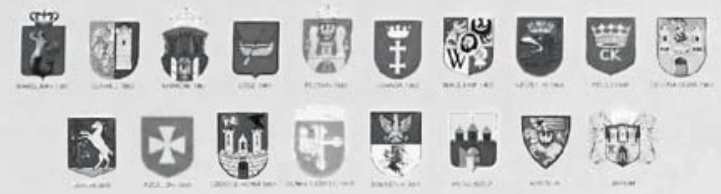

\section{POCZET}

PIERWSZYCH ELEKTRYKÓW POLSKICH

\author{
urodzonych do końca XIX wieku
}
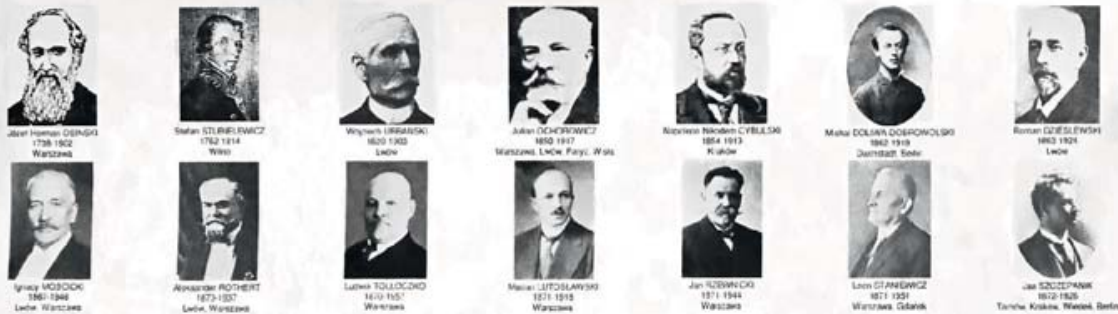

Ryc. 6. Fragment plakatu wydanego przez PTETiS, opracowanie: A. Demenko (pomysł), E. Głowienkowski (grafika), J. Hickiewicz (redakcja); na plakacie brak daty wydania. 
Placet drugiej ważnej organizacji elektryków na posługiwanie się portretem Józefa Hermana Osińskiego otworzył szeroko drzwi dla publikacji o nim, ilustrowanych jego rzekomym portretem. Przykładowe obrazy i ich kompilacje można z łatwością znaleźć w internecie; jedną z bardziej efektownych grafik przedstawiono na Ryc. 8. Spuśćmy zasłonę milczenia na autorów tych ulotnych publikacji.

Prawdziwy wysyp publikacji ilustrowanych portretem Józefa Hermana Osińskiego nastąpił w 2018 r. Stowarzyszenie Elektryków Polskich obrało Osińskiego patronem roku 2018. Bezpośrednim pretekstem była 280 rocznica jego urodzin. W programie obchodów Roku Osińskiego znalazło się m.in. wydanie okolicznościowego kalendarza, szeregu publikacji w czasopismach, monografii książkowej i odsłonięcie pomnika naszego uczonego w Rzeszowie. Wszystkie te dzieła postanowiono udekorować - w dobrej wierze - fałszywym wizerunkiem Osińskiego.

W 2018 r. na stronie internetowej Stowarzyszenia Elektryków Polskich pojawiło się nowe opracowanie graficzne wizerunku Osińskiego z nagłówkiem „Patron roku 2018” (Ryc. 9). Osińskiego odmłodzono i ubrano w strój zakonny. To jednak ewenement, gdyż w pozostałych publikacjach trzymano się "tradycyjnego" portretu.

Na początku 2018 r. opublikowano w „Wiadomościach Elektrotechnicznych” bogato ilustrowany artykuł zatytułowany Ks. Józef Herman Osiński (1738-1802) - pierwszy polski elektryk i autor pierwszego polskiego podręcznika elektrotechniki15; w artykule tym można doliczyć się aż ośmiu powtarzających się rzekomych wizerunków Osińskiego, a dziewiąty jest na okładce czasopisma. Na dodatek sam tytuł wprowadza w błąd, gdyż Osiński nie napisał podręcznika elektrotechniki - takie pojęcie w jego czasach jeszcze nie istniało. Błędnego sformułowania „autor pierwszego polskiego podręcznika elektrotechniki" użył, jako pierwszy, wspomniany już wcześniej Tadeusz Żerański w podtytule swojego artykułu z $1934 \mathrm{r}$.

Zatrzymajmy się dłużej przy książce Ks. Józef Herman Osiński. Pierwszy polski elektryk wydanej w 2018 roku przez Stowarzyszenie Elektryków Polskich ${ }^{16}$. Książka zawiera trzy rozdziały napisane przez trzech różnych autorów: o. Jana Henryka Taffa, Tadeusza Ochenduszkę i Grzegorza Masłowskiego. Teksty wszystkich trzech rozdziałów były wcześniej publikowane w „Zeszytach Naukowych Wydziału Elektrotechniki i Automatyki Politechniki Gdańskiej”. Czy trzeba dodawać, że z okładki książki ponuro spoziera na nas William Thomson?

Na stronie redakcyjnej wydawca nie zamieścił żadnej informacji o grafice umieszczonej na okładce. Odniesienia do wizerunku Józefa Osińskiego znajdują się jednak w treści książki. W rozdziale pierwszym Jan Taff kończy swoje rozważania w następujący sposób:

Zamieszczona w 44 numerze „Zeszytów Naukowych Wydziału Elektrotechniki i Automatyki Politechniki Gdańskiej” dokumentacja I. Sympozjum Historia Elektryki, Gdańsk 29-30.06.2015 zawiera na końcu „Poczet pierwszych elektryków polskich urodzonych do końca XIX wieku", w którym, na pierwszym miejscu, znajduje się

15 G. Masłowski, T. Ochenduszko, B. Pałac, Ks. Józef Herman Osiński (1738-1802) - pierwszy polski elektryk i autor pierwszego polskiego podręcznika elektrotechniki, „Wiadomości Elektrotechniczne” t. 87, 2018, nr 1, s. 43-47.

16 J.H. Taff, T. Ochenduszko, G. Masłowski, Ks. Józef Herman Osiński. Pierwszy polski elektryk. Pionier techniki odgromowej, Rzeszów 2018. 


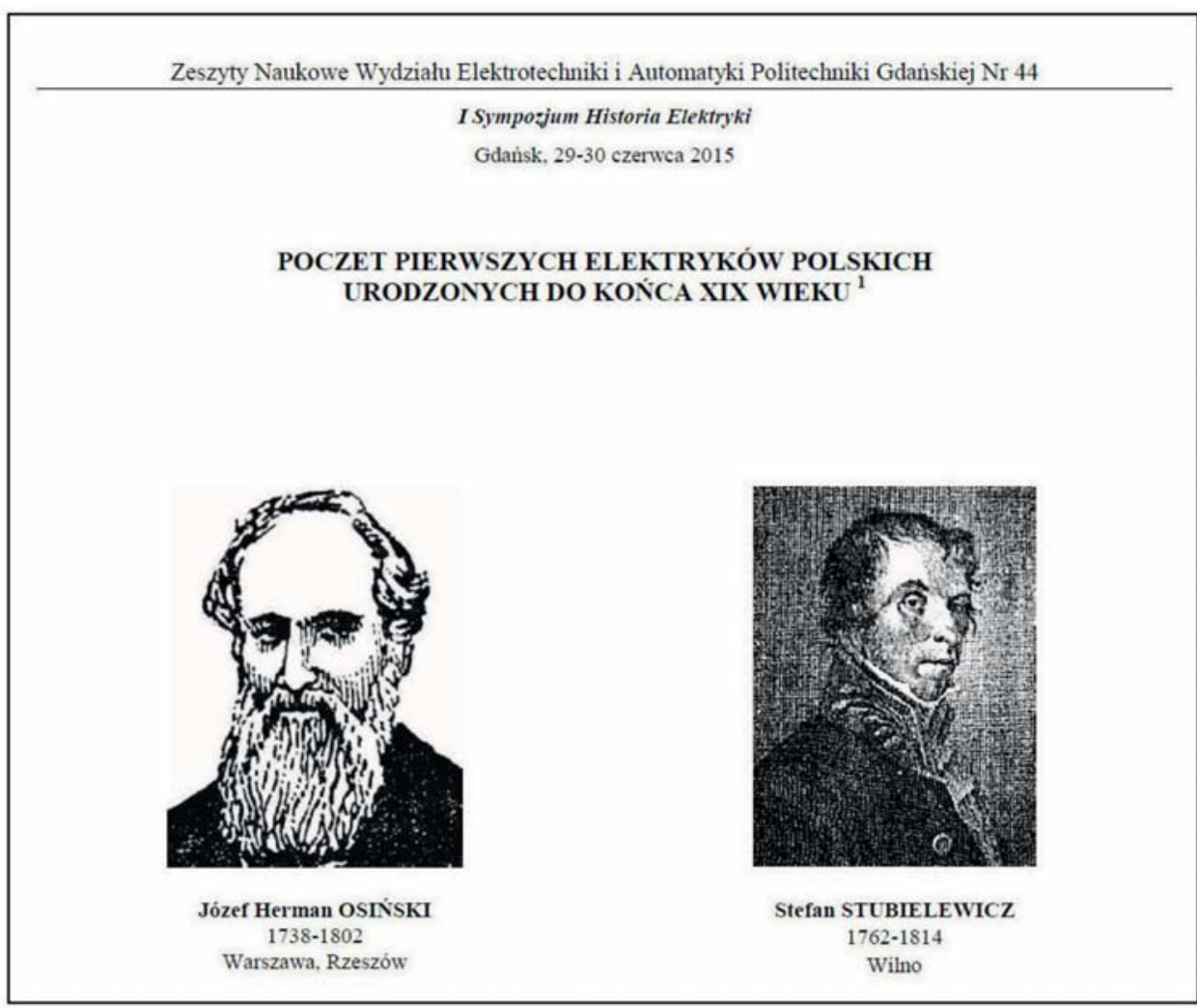

Ryc. 7. Początkowy fragment publikacji A. Demenko i J. Hickiewicza zamieszczonej w materiałach pokonferencyjnych I Sympozjum Historia Elektryki, Gdańsk 2015.

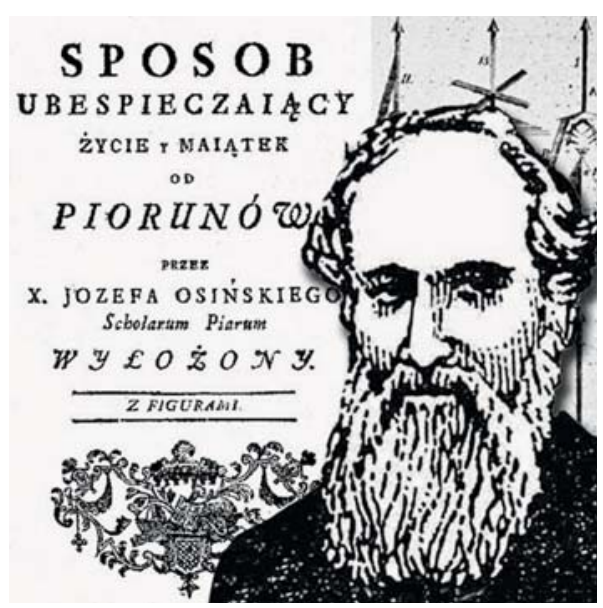

Ryc. 8. Przykład pracy graficznej polegającej na połączenia karty tytułowej książki Osińskiego i jego rzekomego portretu, źródło internetowe, 2013.

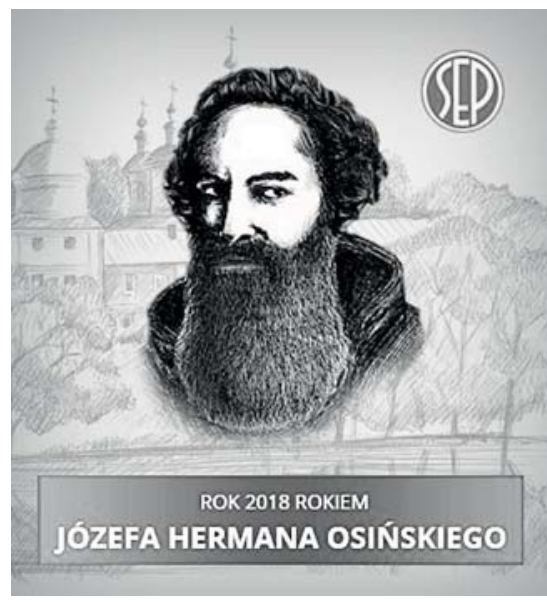

Ryc. 9. Patron roku 2018, grafika ze strony internetowej Stowarzyszenia Elektryków Polskich. 
podobizna ks. Józefa Hermana Osińskiego. Jednakże, jak nie ma obecnie grobu ks. Osińskiego, tak nie ma również jego dokładnego obrazu. Wspomniana wyżej podobizna to pochodząca z późniejszego okresu grafika prawdopodobnego wizerunku. Nie zachował się natomiast żaden portret ks. Osińskiego. A może go nie było? ${ }^{17}$

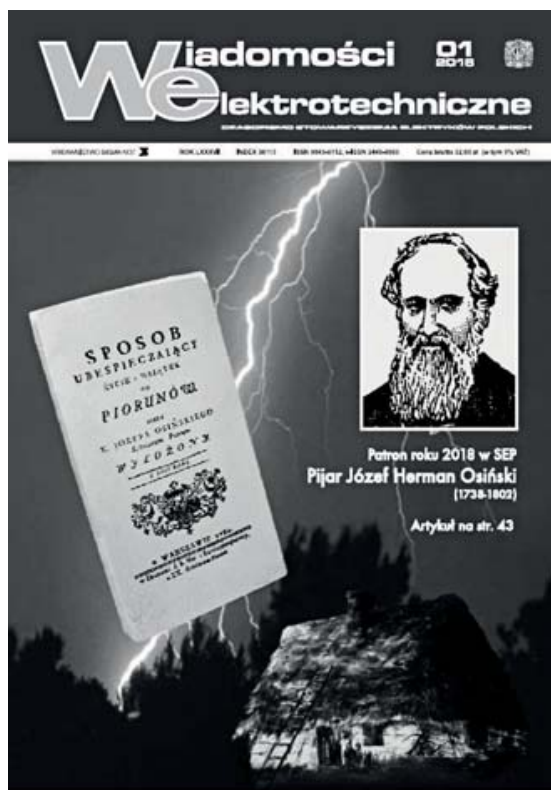

Ryc. 10. Strona tytułowa czasopisma „Wiadomości Elektrotechniczne", nr 1/2018, z zapowiedzią artykułu o Osińskim.

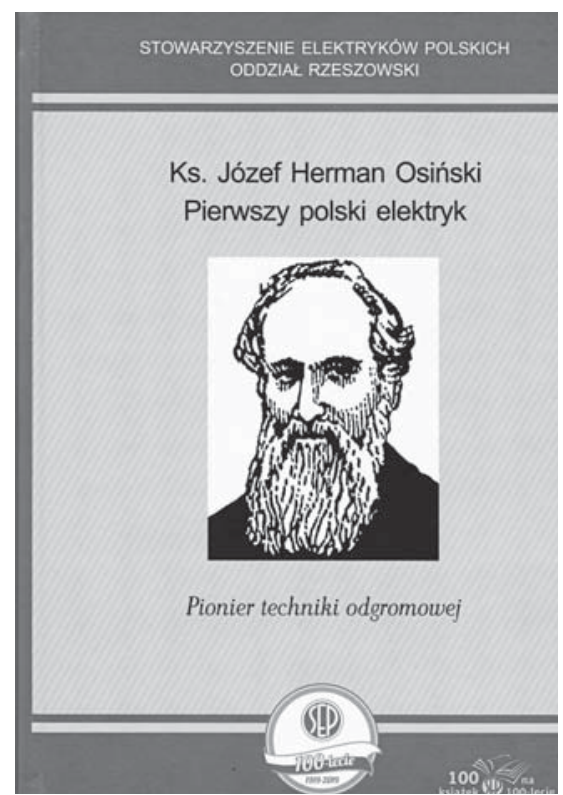

Ryc. 11. Okładka książki o Józefie Osińskim z 2018 r.

Gdyby nie słowa o „prawdopodobnym wizerunku”, można by uznać tę opinię za zgodną z prawdą. Dobrze chociaż, że wreszcie pojawiły się jasno wyrażone wątpliwości co do autentyczności portretu. Dziwne jednak, że autor, pijar, nie zakwestionował „brodatego” portretu, który zupełnie nie pasował do epoki i tradycji zakonnej.

W drugim rozdziale tej samej książki o Osińskim, Tadeusz Ochenduszko pisze bardziej pryncypialnie:

W połowie lat 80. XX w. nauczyciel historii dr Józef Świeboda ustalił i odnotował w swoich publikacjach książkowych, że Osiński był najpierw uczniem, a później wykładowcą w rzeszowskim kolegium. W 2008 r. krótkie wzmianki o „pierwszym elektryku" pojawiły się w książkach wydanych z okazji 350-lecia Szkoły. W tym samym roku wybitny wychowanek został patronem pracowni fizycznej w I Liceum. Jego podobizna i życiorys znajdują się na tabliczce umieszczonej na ścianie obok drzwi wejściowych ${ }^{18}$. 
Rzeczywiście na jednej z fotografii ${ }^{19}$ opublikowanej w artykule w "Wiadomościach Elektrotechnicznych" można zobaczyć widok drzwi do pracowni fizycznej w I Liceum Ogólnokształcącym im. ks. Stanisława Konarskiego w Rzeszowie. Po ich prawej stronie zawieszono tabliczkę z nieprawdziwym portretem Osińskiego, a po stronie lewej plakat PTETiS z pocztem pierwszych polskich elektryków, który rozpoczyna ten sam falsyfikat.

Szkolną tabliczkę można zdjąć lub zastąpić nową już bez portretu, znacznie trudniej będzie z pomnikiem Józefa Osińskiego odsłoniętym we wrześniu 2018 r. w Rzeszowie. Pomnik Osińskiego stanął na skwerze jego imienia z inicjatywy Stowarzyszenia Elektryków Polskich. Jego ciekawą formę architektoniczną - dwie duże szklane tafle ustawione na postumentach - unieważnia, niestety, umieszczony na jednej z nich falsyfikat portretu Osińskiego. Nie wiemy, jakie rozwiązanie tej sprawy podejmą fundatorzy pomnika i włodarze miasta.

Pomnik Osińskiego to kulminacyjny punkt kariery przypadkowego wizerunku. Miejmy nadzieję, że po wyjaśnieniu wszystkich okoliczności uznania wizerunku lorda Kelvina za podobiznę Józefa Hermana Osińskiego nastąpi odwrót od tej praktyki.

\section{Ofiary pomyłki}

Lista osób, instytucji, redakcji, rad naukowych i komisji, które dały się nabrać na fałszywą podobiznę Józefa Hermana Osińskiego jest długa. Wymienimy ją dla przestrogi innych badaczy i autorów, przypominając, że dystans i wątpliwość w wiarygodność źródeł literaturowych i ikonograficznych są podstawą warsztatu historyka. Podążanie za głosem większości, za zdawałoby się pewnie ustaloną wiedzą, czy też przeciwnie - za chwilową modą, zwykle nie prowadzi do rozwoju nauki. Przedstawione w artykule konsekwencje prostej pomyłki sprzed lat są zatrważające. W łańcuchu dziesiątek utytułowanych osób, podążających błędną drogą przez co najmniej ostatnie ćwierćwiecze, nie znalazł się nikt, kto zainteresowałby się źródłem pochodzenia nieznanego portretu, jego autorem, czasem powstania, a przede wszystkim zgodnością z prawdą. Lista ofiar pomyłki zapewne nie będzie kompletna, ale spróbujmy ułożyć ją chronologicznie.

Dr inż. Andrzej Marusak oraz dr hab. inż. Jacek Przygodzki - członkowie komisji powołanej w 1984 roku przez Zarząd Główny Polskiego Towarzystwa Elektrotechniki 
Teoretycznej i Stosowanej - autorzy Pocztu ośmiu Wielkich Elektryków Polskich.

Prof. dr hab. inż. Andrzej Demenko i dr hab. inż. Jerzy Hickiewicz - autorzy plakatu i artykułu (2015) zatytułowanego Poczet pierwszych elektryków polskich urodzonych do końca XIX wieku.

Komitet Naukowy Sympozjum Historia Elektryki, Gdańsk 2018 - publikacja Pocztu pierwszych elektryków polskich urodzonych do końca XIX wieku w materiałach konferencyjnych.

I Liceum Ogólnokształcące im. ks. Stanisława Konarskiego w Rzeszowie - tabliczka przed gabinetem fizycznym.

Dr Tadeusz Ochenduszko - współautor książki Ks. Józef Herman Osiński. Pierwszy polski elektryk. Pionier techniki odgromowej.

Dr hab. inż. Grzegorz Masłowski, dr Tadeusz Ochenduszko, mgr inż. Bolesław Pałac - autorzy artykułu Ks. Józef Herman Osiński (1738-1802) - pierwszy polski elektryk $i$ autor pierwszego polskiego podręcznika elektrotechniki.

Stowarzyszenie Elektryków Polskich, Zarząd Główny - opracowanie i używanie logotypu Rok 2018 rokiem Józefa Hermana Osińskiego.

Centralna Komisja Historyczna Stowarzyszenia Elektryków Polskich - brak reakcji na publikację fałszywego wizerunku „pierwszego elektryka” używanego podczas obchodów Roku Osińskiego.

Stowarzyszenie Elektryków Polskich, Oddział Rzeszowski - wydawca książki Ks. Józef Herman Osiński. Pierwszy polski elektryk. Pionier techniki odgromowej oraz kalendarza na rok 2018 nazwany Rokiem Osińskiego

Autorzy pomnika Józefa Hermana Osińskiego na skwerze jego imienia w Rzeszowie (2018).

\section{Zamiast sentencji wyroku}

Sprawa falsyfikatu wizerunku Józefa Hermana Osińskiego nie musiała się wydarzyć. Zbieg okoliczności sprawił, że przed pięćdziesięciu laty w redakcji Instytutu Wydawniczego „Nasza Księgarnia” anonimowy redaktor nieprawidłowo połączył ilustrację z tekstem. Ta drobna pomyłka miała ogromne konsekwencje. Powielanie błędu, które nastąpiło w ostatnich kilku latach i spowodowało rozpowszechnienie na szeroką skalę nieprawdziwej informacji o wyglądzie polskiego uczonego, jest symptomem nowego podejścia do informacji tekstowej i graficznej.

Żyjemy w czasach bardzo łatwego dostępu do informacji. Dzięki nowoczesnym mediom, a zwłaszcza za sprawą internetu, liczba informacji i szybkość ich obiegu stale się zwiększa. Problemem jest selekcja informacji prawdziwych od fałszywych. Sprzyja temu anonimowość wielu nowoczesnych źródeł informacji. Nieprzypadkowo bańka z podróbką portretu Osińskiego urosła tak szybko właśnie w ostatnich latach. Nieopisana grafika, bez nazwiska autora, daty powstania i prawidłowego opisu treści rozpowszechniła się między innymi za sprawą umieszczenia jej w internecie. Dziś łatwiej jest wprowadzić do obiegu nieprawdziwą wiadomość, niż ją skutecznie sprostować, nie mówiąc o usunięciu. Z obrazem jest nawet trudniej niż z tekstem. 
Zapewne spore grono czytelników zdążyło już trwale skojarzyć osobę Józefa Hermana Osińskiego z portretem z brodą. Zobaczymy w najbliższych latach, na ile skuteczna była praca włożona w nasz proces poszlakowy, poparty mocnymi dowodami.

\section{Bibliografia}

I Sympozjum Historia Elektryki, SHE'2015, cz. 2, „Zeszyty Naukowe Wydziału Elektrotechniki i Automatyki Politechniki Gdańskiej" nr 44, Gdańsk 2015.

Demenko A., Hickiewicz J., Poczet pierwszych elektryków polskich urodzonych do końca XIX wieku, „Zeszyty Naukowe Wydziału Elektrotechniki i Automatyki Politechniki Gdańskiej" nr 44, s. 117-125.

"Gazeta Warszawska", 1.05.1779.

Kraushar A., Towarzystwo Warszawskie Przyjaciół Nauk 1800-1832, t. 1-9, KrakówWarszawa 1900-1911.

Kubiatowski J., Biogram Eugeniusza Jana Porębskiego, [w:] Internetowy Polski Słownik Biograficzny, ipsb.nina.gov.pl/a/biografia/eugeniusz-jan-porebski [dostęp 6.12.2019].

Taff J.H., Ochenduszko T., Masłowski G., Ks. Józef Herman Osiński. Pierwszy polski elektryk. Pionier techniki odgromowej, Rzeszów 2018.

Masłowski G., Ochenduszko T., Pałac B., Ks. Józef Herman Osiński (1738-1802) pierwszy polski elektryk $i$ autor pierwszego polskiego podręcznika elektrotechniki, „Wiadomości Elektrotechniczne” t. 87, 2018, nr 1, s. 43-47.

Mowa miana przez Stanisława Sołtyka na pamiątkę X. Osińskiego Piiara, dnia 24 Maia 1804 roku, „Roczniki Towarzystwa Warszawskiego Przyjaciół Nauk” t. 4, Warszawa 1807, s. 12-30;

Mowa miana przez Stanisława Sołtyka na pamiątkę X. Osińskiego Piiara, dnia 24 Maia 1804 roku, „Nowy Pamiętnik Warszawski” t. 15, lipiec 1804, s. 109-126.

Orgelbranda Encyklopedja powszechna z ilustracjami i mapami, t. 1-18, Warszawa 1898-1912.

Orłowski B., Z. Wójcik, Jerzy Kubiatowski (1922-1995), „Kwartalnik Historii Nauki i Techniki" t. 41, 1996, nr 2, s. 145-152.

Osiński J.H., Fizyka doświadczeniami potwierdzona, Warszawa 1777.

Osiński J.H., Nauka o gatunkach i szukaniu rudy żelazney, Warszawa 1782.

Osiński J.H., Sposob ubespieczający życie y maiątek od piorunów, Warszawa 1784.

Osiński J.H., Gatunki powietrza odmiennego od tego, w ktorem żyjemy, krodko zebrane, sposoby nabywania ich opisane, własności doswiadczeniami potwierdzone, zażycie iednych do robienia wod leczących, lub strzelania, innych na dochodzenie, ktore powietrze zdrowe etc., Warszawa 1783.

Osiński J.H., Robota machiny powietrznej pana Mongolfier, Warszawa 1784.

Osiński J.H., Fizyka naynowszemi odkryciami pomnożona, nayoczywistrzemi doświadczeniami potwierdzona, t. 1, Warszawa 1801, t. 2, Warszawa 1803.

Osiński J.H., Fizyka X. Józefa Osińskiego S.P. przerobiona y naynowszemi odkryciami pomnożona przez X. Jana Bystrzyckiego S.P., tom I, Warszawa 1810, tom II, Warszawa 1806. 
Pierwsze publiczne odczyty w Warszawie, "Tygodnik llustrowany" t. 2, 1868, s.167.

Porębski E., Wielcy twórcy nauki, wyd. 1, Warszawa 1934, wyd. 2, Warszawa 1939.

Polskie Towarzystwo Elektrotechniki Teoretycznej i Stosowanej, Wielcy Elektrycy Polscy, marie-www.ee.pw.edu.pl/sep-ow/PLI/wep.htm [dostęp 6.12.2018].

Rogaliński J., O Dziwnych Bursztynowania Skutkach Rozmowa y Popis Publiczny z Wytłumaczeniem Niektórych szczegulnieyszych Doswiadczen, Poznań 1766.

Sobiesiak R., Poczet wielkich fizyków, Warszawa 1969.

Weinfeld S., Poczet wielkich elektryków, Warszawa 1968.

Weinfeld S., Poczet wielkich elektryków, Warszawa 1968, rec. J. Kubiatowski, „Kwartalnik Historii Nauki i Techniki" t. 15, 1970, nr 2, s. 367-368.

Wielka Encyklopedja Powszechna Ilustrowana, t. 1-55, Warszawa 1892-1914.

Wróblewski A. K., Historia fizyki, Warszawa 2006.

Żerański T., Ks. Józef Herman Osiński, pierwszy elektryk polski (W 150-tą rocznicę ogłoszenia drukiem pierwszej polskiej książki elektrotechnicznej), „Przegląd Elektrotechniczny" t. 16, 1934, nr 14, s. 449-452.

dr inż. Jerzy Sawicki - elektrotechnik, nauczyciel akademicki w Katedrze Inżynierii Systemów, Sygnałów i Elektroniki na Wydziale Elektrycznym Zachodniopomorskiego Uniwersytetu Technologicznego w Szczecinie; autor m.in. książki Ewald Georg Kleist: Wielki odkrywca z małego miasta. Kamień Pomorski 1745 (IHN PAN, 2018). E-mail: jerzy.sawicki@zut.edu.pl

Andrzej Kajetan Wróblewski - fizyk i historyk fizyki, emerytowany profesor Wydziału Fizyki Uniwersytetu Warszawskiego, autor m.in. książki Historia Fizyki (PWN Warszawa, 2006), przewodniczący Rady Naukowej IHN PAN w latach 19962018. E-mail: akw@fuw.edu.pl

Data zgłoszenia artykułu: 6 grudnia 2018

Data przyjęcia do druku: 22 lutego 2019 